\title{
Determination of copper in sugarcane spirit by flame atomic absorption spectrometry using a ternary solvent mixture (water-ethanol-acetone)
}

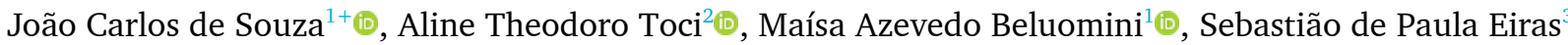 \\ ${ }^{1}$ São Paulo State University (Unesp), Institute of Chemistry, Araraquara, 55 Prof. Francisco Degni St, Araraquara, São Paulo 14800-060, Brazil \\ ${ }^{2}$ Federal University for Latin American Integration, Centro de Ciências da Natureza, 1842 Silvio Américo Sasdelli Av, Foz do Iguaçu, Paraná \\ 85867-970, Brazil \\ ${ }^{3}$ Universidade Federal de Uberlândia, Campus Santa Mônica, Instituto de Química, Departamento de Química Analítica, 2121 João Naves de \\ Ávila Av, Uberlândia, Minas Gerais 38400-902, Brazil
}

+ Corresponding author: João Carlos de Souza, phone: +55 16 3301-9519, e-mail address: souza_jc33@yahoo.com.br

\section{ARTICLE INFO}

Article history:

Received: October 09, 2017

Accepted: November 10, 2017

Published: December 30, 2017

\author{
Keywords: \\ 1. copper \\ 2. sugarcane spirit \\ 3. homogeneous ternary solvent mixture \\ 4. flame atomic absorption spectrometry \\ 5. single phase solution
}

ABSTRACT: The present work describes the use of a homogeneous ternary mixture of the solvents water, ethanol, and acetone to improve the determination of copper in sugarcane spirit by flame atomic absorption spectrometry. The solvent ratio used (on a volume basis) was 5.0:5.0:15.0 (water:ethanol:acetone). The analytical curve for copper was linear up to a concentration of $6.00 \mathrm{mg} \mathrm{L}^{-1}$ of copper, and could be described by the equation: $\Delta \mathrm{Abs}=0.1778 \mathrm{C}_{\mathrm{Cu}}+0.0048\left(\mathrm{r}^{2}=0.9999\right)$, and limits of detection and quantification (calculated using the standard deviation of the blank) were 0.01 and $0.05 \mathrm{mg} \mathrm{L}^{-1}$ of copper, respectively. Use of the proposed homogeneous ternary solvent system provided good stability and a significant increase in sensitivity compared to reference methodology. This increase in sensitivity enables the detection of smaller quantities of copper in sugarcane spirit. The method was applied to determine copper in commercial brands of sugarcane spirits. The results obtained by the proposed method were favorably compared with those given by the reference method.

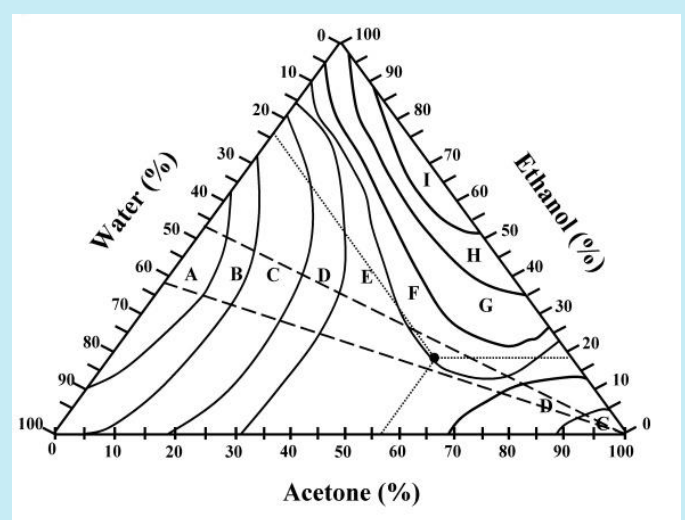

Absorbance values for the regions: $A<B<C<D<E<F<G<H<I<J$.

\section{Introduction}

It is important to be able to determine metals at trace levels in different matrices, because although at low concentrations many elements are essential in human biological processes, at higher concentrations they can act as toxins and become prejudicial to health ${ }^{1}$.

In the human organism, copper plays a fundamental role as a cofactor of several enzymes, as well as in the uptake of iron ${ }^{2-6}$. At normal concentrations, it participates in activities involving tyrosinase, cytochrome oxidase, and ceruloplasmin ${ }^{7-10}$. On the other hand, an excess of copper in the organism causes interference in the catalytic activities of several enzymes, and can lead to neurodegenerative diseases such as Wilson's disease, Menkes syndrome, aceruloplasminemia, sclerosis, rheumatoid arthritis, Alzheimer's disease, and autism death $^{7-16}$. In excess, copper can also be carcinogenic and cause melanoma, a malignant cancer characterized by the appearance of black growths on the skin, leading to blindness and death ${ }^{7-10}$.

In Brazil, sugarcane spirit is defined by Normative Instruction $\mathrm{n}^{\circ} 13$ of 29 July 2005, of the Ministry of Agriculture, Livestock and Supply (MAPA), as a drink with an alcohol content between 38 and $54 \%$ (v/v) at 20 ${ }^{\circ} \mathrm{C}$, obtained by the simple alcoholic distillation of 
sugarcane, or by distillation of the fermented must of sugarcane $^{17}$. It is normally produced using copper stills, which provides a better quality product, compared to stills manufactured using other materials such as stainless steel. Many studies have described a catalytic role of copper during the distillation process, contributing to the elimination of undesirable odors found in spirits distilled using equipment composed of other materials. Nevertheless, the use of copper stills can result in contamination of the product with the metal, especially following inappropriate cleaning procedures ${ }^{18-20}$. The contamination occurs during the distillation process, when the copper that comprises the internal walls of the still is exposed to humid air containing carbon dioxide, becoming slowly oxidized and coated with a greencolored layer of copper(II) dihydroxycarbonate $\left(\mathrm{CuCO}_{3} \mathrm{Cu}(\mathrm{OH})_{2}\right)$, commonly known as verdigris. This compound can be dissolved by the acidic and alcoholic vapors, hence contaminating the distillate ${ }^{11,18,20-22}$. For these reasons, the copper content of sugarcane spirit is regulated by national legislation, with a maximum concentration of $5.00 \mathrm{mg} \mathrm{L}^{-1}$ permitted in commercial products $^{17,23}$. In the European Community, for example, the maximum content of copper permitted in alcoholic distillates is $2.00 \mathrm{mg} \mathrm{L}^{-124}$.

Organic solvents can be used to increase the sensitivity of analytical measurements performed using flame atomic absorption spectrometry (FAAS), by improving the processes of nebulization and combustion of the sample $\mathrm{e}^{25-27}$. However, if the organic solvent is simply inserted into originally aqueous samples, the measurements can show poor reproducibility and operational errors can occur when solvents are changed ${ }^{28}$. The use of a homogeneous mixture of solvents, also called a single phase solution, is advantageous, because the single phase then presents mixed properties analogous of both water and organic solvents, and has the capacity to dissolve both organic and inorganic compounds ${ }^{29}$. This type of single phase solution can be used in a variety of different analytical techniques.

Ternary solvent mixtures have been used in FAAS analyses $^{28,29}$, providing a significant increase in sensitivity and good reproducibility for a single phase system composed of the solvents water, ethanol, and acetone, compared to purely aqueous systems. An additional benefit is that the use of ternary solvent systems substantially reduces the cost of analysis, avoiding the use of pure solvents ${ }^{29}$.

To the best of our knowledge, there is not report on the use of the ternary solvent mixture combined with FAAS analytical method for the determination of copper in sugarcane spirits. Thus, the aim of the present study was to improve the methodology for detection of copper in sugarcane spirit, employing FAAS with a homogeneous ternary mixture of the solvents water, ethanol, and acetone.

\section{Materials and methods}

\subsection{Apparatus}

The absorbance measurements were performed using a Hitachi Z-8200 flame atomic absorption instrument (Mitorika, Ibaraki, Japan) equipped with polarized Zeeman effect background correction and a hollow cathode copper lamp (Hitachi model 208-2011). The operating conditions were: lamp current of $10 \mathrm{~mA}$, wavelength of $324 \mathrm{~nm}$, slit width of $1.3 \mathrm{~nm}$, burner height of $7.5 \mathrm{~mm}$, oxidizing gas (air) flow rate of $15 \mathrm{~L} \mathrm{~min}^{-1}$, and fuel gas (acetylene) flow rate of $2.2 \mathrm{~L} \mathrm{~min}^{-1}$. All the absorbance measurements were performed in triplicate.

\subsection{Phase diagram and determination of proportions of solvents in the ternary system}

Ten different proportions of solvents were chosen to produce the water-ethanol-acetone phase diagram, according to the Figure 1, as recommended by Cornell ${ }^{30}$ for this type of study. The compositions of the mixtures of solvents were determined such that the individual points were distributed symmetrically throughout the ternary solvent diagram. The concentration of copper was maintained constant at $2.50 \mathrm{mg} \mathrm{L}^{-1}$ (inserted using the aqueous fraction of the solvent mixture).

The results of the absorbance measurements were treated according to the procedure described by Arthur System $^{31,32}$. In the phase diagram obtained, the working region was demarcated considering the range of alcohol contents of sugarcane spirit $(38-54 \%, \mathrm{v} / \mathrm{v})$. Within this region, selection was made of the composition of the single phase solution of the three solvents that provided best sensitivity. The absorbance measurements were performed using a Hitachi Z-8200 flame atomic absorption instrument (Mitorika, Ibaraki, Japan) equipped with polarized Zeeman effect background correction and a hollow cathode copper lamp (Hitachi model 208-2010). The operating conditions were: wavelength of $324 \mathrm{~nm}$, slit width of $1.0 \mathrm{~nm}$, burner height of $7.4 \mathrm{~mm}$, oxidizing gas (air) flow rate of $12 \mathrm{~L} \mathrm{~min}^{-1}$, and fuel gas (acetylene) flow rate of $2.0 \mathrm{~L} \mathrm{~min}^{-1}$. All the absorbance measurements were performed in triplicate. 


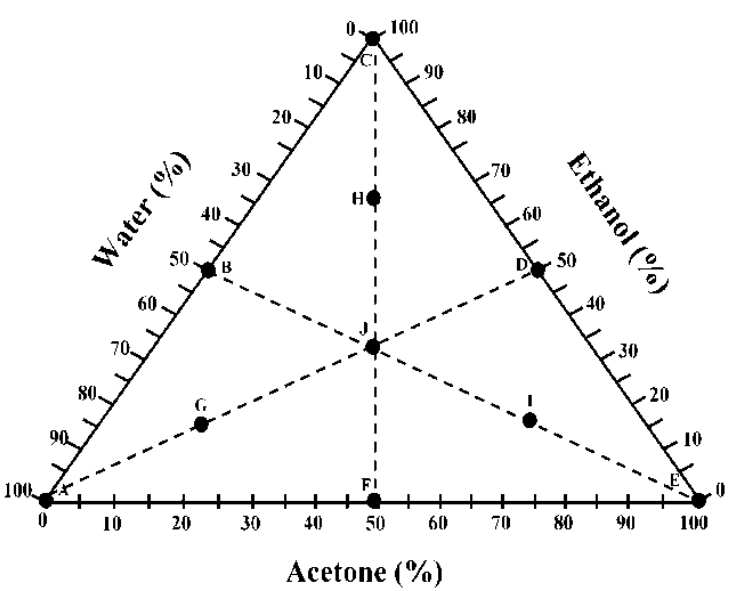

Figure 1. Water-ethanol-acetone phase diagram indicating the points corresponding to the different proportions of solvents employed (\%,w/w).

\subsection{Analytical calibration curves}

Calibration curves were constructed using six points, with the concentration of copper varied from 1.00 to 6.00 $\mathrm{mg} \mathrm{L}^{-1}$. The first curve was prepared using the methodology for analysis of alcoholic distillates, with aqueous solutions containing $50.0 \% \quad(\mathrm{v} / \mathrm{v})$ ethanol (reference method) [33]. The second curve was constructed using the homogeneous ternary waterethanol-acetone solvent mixture, employing the proportions of solvents established in the preceding step (5.0:5.0:15.0, $\mathrm{v} / \mathrm{v}$, respectively), with the copper being introduced in the aqueous portion of the single phase system. All the absorbance measurements were performed using the same instrumental conditions described previously.

\subsection{Evaluation of the precision and accuracy of the method}

Four samples of sugarcane spirit were simulated in the laboratory, using an aqueous solution containing around $50 \%(\mathrm{v} / \mathrm{v})$ of ethanol. The alcohol content was measured using a densitometer specific for alcohol. The samples were spiked with different concentrations of copper (1.00, $3.00,5.00$ and $6.00 \mathrm{mg} \mathrm{L}^{-1}$ ) and analyzed using the single phase methodology, and the reference methodology in quintuplicate, under the instrumental conditions described above (section 2.1.). In the case of the reference method, prior to analysis the samples were analyzed directly, without prior treatment (Association of Official

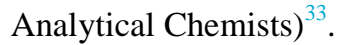

For the single phase procedure, an aliquot of $10.0 \mathrm{~mL}$ of each simulated sugarcane spirit sample was transferred to a beaker. Considering that the samples consisted of a mixture of water and ethanol, a $15.0 \mathrm{~mL}$ volume of acetone was added in order to comply with the proportions of solvents established previously (5.0:5.0:15.0, v/v, of water-ethanol-acetone).

\subsection{Determination of copper in commercial samples of sugarcane spirit}

Analysis was made of seven samples of sugarcane spirit brands commonly available in local supermarkets. The alcohol contents were determined using an alcohol densitometer, and each sample was analyzed by both methods, in quintuplicate, under the conditions described above (section 2.1.). For analysis using the reference method, the samples were analyzed directly, without prior treatment, and in the single phase procedure, an aliquot of $10.0 \mathrm{~mL}$ of each sample was transferred to a beaker, followed by addition of $15.0 \mathrm{~mL}$ of acetone.

\section{Results and discussion}

\subsection{Phase diagram and determination of the proportions} of solvents in the ternary system

The influence of the solvents was evaluated using the contours of the phase diagram (Figure 2), as described by Arthur System ${ }^{31,32}$. From the response surface curves, it can be seen that the absorbance increased from region "A" to region "I", according to the Figure 2. The region corresponding to the alcohol content of sugarcane spirit $(38-54 \%, v / v$, equivalent to water content between 62 and $46 \%,(\mathrm{v} / \mathrm{v})$ is indicated by the dashed lines in the phase diagram. Within this region, the space delimited by curve "F" indicates the greatest sensitivity. The point corresponding to a water-ethanol-acetone composition of 24.0:19.0:57.0\% $(\mathrm{w} / \mathrm{w})$ (indicated in the phase diagram) was therefore adopted as providing the highest sensitivity. This composition was equivalent to a 5.0:5.0:15.0 (v/v) mixture of water-ethanol-acetone.

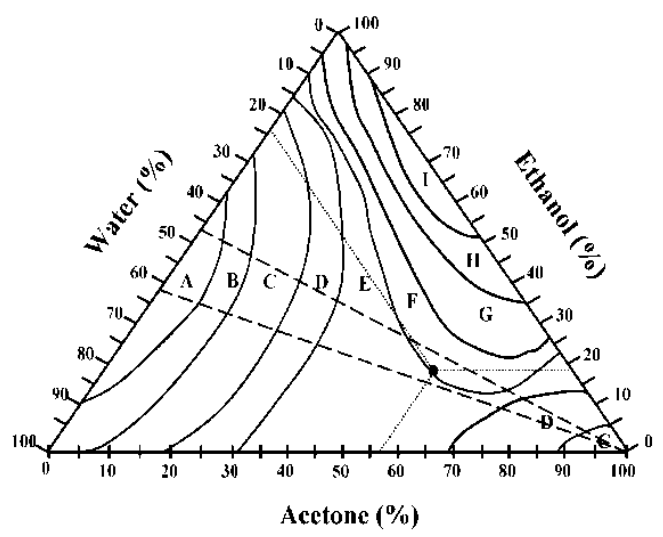

Absorbance values for the regions: $A<B<C<D<E<F<G<H<\mid<J$.

Figure 2. Response surface curves for absorbance as a function of the composition of the water-ethanol-acetone solvent mixture $(\%, \mathrm{w} / \mathrm{w})$. 


\subsection{Analytical calibration curves}

The calibration curves obtained for the reference and single phase methodologies are shown in Figure 3.

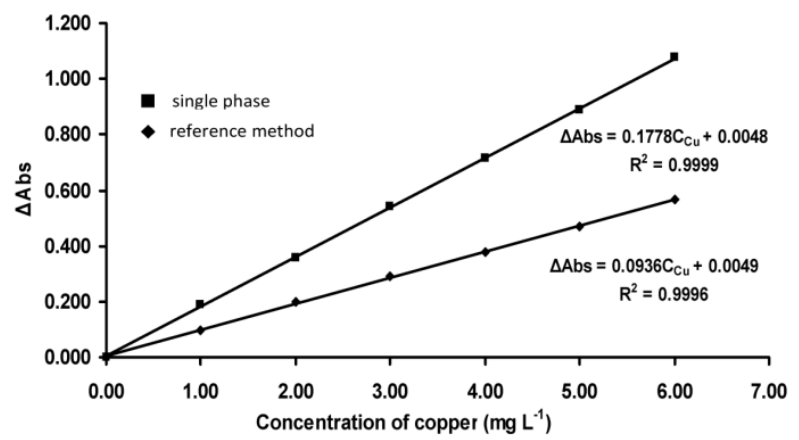

Figure 3. Calibration curves for copper using the reference and single phase solution methods.

The analytical curve for single phase method presented linearity up to $6.00 \mathrm{mg} \mathrm{L} \mathrm{L}^{-1}$, and could be described by the equation: $\Delta \mathrm{Abs}=0.1778 \mathrm{C}_{\mathrm{Cu}}+0.0048$ $\left(\mathrm{r}^{2}=0.9999\right)$. The detection and quantification limits were 0.01 and $0.05 \mathrm{mg} \mathrm{L}^{-1}$, respectively, calculated using the standard deviation of the reagent blank by the equations ${ }^{34}$ :

LOD $=3 \times$ (blank standard deviation) / slope (Equation 1) ${ }^{34}$
LOQ $=10 \times$ (blank standard deviation) / slope (Equation 2) ${ }^{34}$

\author{
Note: LOD: Limit of detection \\ LOQ: Limit of quantification \\ Slope: Angular coefficient of the analytical curve
}

Comparison of the two analytical curves revealed that use of the single phase solution resulted in a significant gain in sensitivity, of $90.0 \%$ (calculated using the angular coefficients of the straight lines), relative to the reference method. This gain in sensitivity was due to improvement in the sample nebulization process caused by the presence of acetone, which increased the flame temperature of the FAAS system. This confirmed the advantages of the single phase methodology for the detection of copper at lower concentrations in sugarcane spirit.

\subsection{Precision and accuracy of the method}

The precision and accuracy of the determinations of copper using the reference and single phase methodologies were evaluated by spiking simulated samples of sugarcane spirit prepared in the laboratory. The alcohol content used was $50 \%$ (v/v), which was approximately equivalent to the average alcohol content of commercial products. Table 1 provides the recovery results, together with the associated standard deviations and analytical errors.

Table 1. Recoveries of copper from the simulated samples of sugarcane spirit together with associated standard deviations and relative errors.

\begin{tabular}{cccc}
\hline Simulated samples & $\begin{array}{c}{[\mathbf{C u}] \text { added }} \\
\left(\mathbf{m g ~ L}^{-\mathbf{1}}\right)\end{array}$ & $\begin{array}{c}{[\mathbf{C u}] \text { reference method }} \\
\left(\mathbf{m g ~ L}^{-\mathbf{1}}\right)\end{array}$ & $\begin{array}{c}{[\mathbf{C u}] \text { single phase method }} \\
\left(\mathbf{m g ~ L}^{-\mathbf{1}}\right)\end{array}$ \\
\hline 1 & 1.00 & $0.98 \pm 0.12$ & $1.01 \pm 0.06$ \\
2 & 3.00 & $3.11 \pm 0.15$ & $3.04 \pm 0.08$ \\
3 & 5.00 & $4.89 \pm 0.11$ & $5.07 \pm 0.01$ \\
4 & 6.00 & $5.95 \pm 0.05$ & $5.92 \pm 0.03$ \\
\hline
\end{tabular}

It can be seen that at both $1.00 \mathrm{mg} \mathrm{L}^{-1}$ and the maximum concentration established according to Brazilian legislation $\left(5.00 \mathrm{mg} \mathrm{L}^{-1}\right)$, the relative error obtained for both methodologies was within the acceptable range $(\leq 5.0 \%)$. The accuracy of the single phase solution method was also satisfactory, with errors below $2.0 \%$ for copper concentrations between 1.00 and $5.00 \mathrm{mg} \mathrm{L}^{-1}$. The proposed method therefore provided greater accuracy than the reference method, for which average relative errors were $\geq 2.0 \%$, according to the
Table 1. The new method also showed standard deviation values below 0.1 , while the values obtained for the standard method were between 0.11 and 0.22 .

\subsection{Application of the methodology in the determination of copper in samples of commercial sugarcane spirit}

Seven commercial brands of sugarcane spirit available in supermarkets and specialized shops were used to compare the proposed single phase methodology with the reference method, according to the Table 2. 
Table 2. Concentrations of copper in samples of commercial sugarcane spirit.

\begin{tabular}{|c|c|c|c|c|}
\hline Sample & $\begin{array}{c}\text { Alcohol content (\% } \\
\text { v/v) }\end{array}$ & $\begin{array}{c}{[\mathrm{Cu}]} \\
\text { reference method } \\
\left(\mathrm{mg} \mathrm{L}^{-1}\right)\end{array}$ & $\begin{array}{c}{[\mathrm{Cu}]} \\
\text { Single phase method (mg } \\
\left.\mathbf{L}^{-1}\right)\end{array}$ & Test " $t$ " value* \\
\hline 1 & 40.0 & $2.51 \pm 0.02$ & $2.54 \pm 0.01$ & 1.94 \\
\hline 2 & 42.0 & $1.13 \pm 0.03$ & $1.11 \pm 0.04$ & 1.73 \\
\hline 3 & 46.0 & $0.74 \pm 0.01$ & $0.72 \pm 0.02$ & 1.40 \\
\hline 4 & 38.0 & $0.69 \pm 0.02$ & $0.71 \pm 0.03$ & 1.88 \\
\hline 5 & 39.0 & $1.23 \pm 0.03$ & $1.20 \pm 0.02$ & 1.68 \\
\hline 6 & 40.0 & $0.97 \pm 0.04$ & $1.00 \pm 0.08$ & 1.18 \\
\hline 7 & 42.0 & $0.84 \pm 0.03$ & $0.86 \pm 0.04$ & 0.96 \\
\hline
\end{tabular}

*Note: Test "t" performed at $95 \%$ confidence level, $\mathrm{n}=5$;

Critical value of " $\mathrm{t}$ " at $95 \%$ confidence level $=2,776$.

The results obtained by the proposed method showed good agreement with those obtained by the official method, according to the Table 2. For all analyzed formulations, the results obtained by both methods were compared using $t$-tests at $95 \%$ confidence level. For all cases, calculated " $t$ " values did not exceed the critical values, indicating that there was no significant difference between both methods in concerning precision and accuracy.

Considering that the determination of copper in sugarcane spirit is needed due to the toxicity of copper to the human organism, and that the quantities of the drink consumed in Brazil and elsewhere ${ }^{35}$ are increasing, it should be noted that none of the samples analyzed contained copper at concentrations exceeding the limit established by Brazilian legislation $\left(5.00 \mathrm{mg} \mathrm{L}^{-1}\right.$ of copper) [17]. These results are indicative of satisfactory care and cleaning of the stills used to produce sugarcane spirit (for the brands analyzed). Nonetheless, the copper concentrations measured (using the reference method) in Sample 1 was $2.51 \mathrm{mg} \mathrm{L}^{-1}$, respectively, which exceeded the acceptable limit of $2.00 \mathrm{mg} \mathrm{L}^{-1}$ established by the European Union ${ }^{25}$ (which would make the products unsuitable for the export market).

\section{Conclusions}

The proposed method, using the addition of acetone to sugarcane spirit to produce a mixture of solvents, resulted in a significant $90 \%$ gain in sensitivity, relative to the reference method. This gain in sensitivity enables the quantification of lower concentrations of copper in sugarcane spirit. The reliability of the new method was satisfactory, since it provided good accuracy, and measurement stability. The values obtained for all of these parameters were superior to those achieved using the reference method. The use of a solvent consisting of a single phase solution of water-ethanol-acetone, in a ratio of 5.0:5.0:15.0 (v/v), offers significant advantages for the analysis of copper in samples of sugarcane spirit using flame atomic absorption spectrometry.

The commercial samples of sugarcane spirit analyzed did not contain levels of copper that exceeded the limit set by Brazilian legislation. Nonetheless, some of the samples contained copper at concentrations above the European Union limit value, and these products would therefore not be suitable for export.

\section{Acknowledgments}

The authors do sincerely acknowledge their indebtedness and gratitude to the Institute of Chemistry of the Universidade Federal de Uberlândia for the provision of resources.

\section{References}

[1] Bispo, M. S., Korn, M. G. A., Boa Morte, E. S., Teixeira, L. S. G., Determination of lead in seawater by inductively coupled plasma optical emission spectrometry after separation and pre-concentration with cocrystallized naphthalene alizarin, Spectrochim. Acta B 57 (1) (2002) 2175-2180. 8547(02)00179-9.

https://doi.org/10.1016/S0584-

[2] Shanmuganathan, A., Avery, S. V., Willetts, S. A., Houghton, J. E., Copper-induced oxidative stress in Saccharomyces cerevisiae targets enzymes of the glycolytic pathway, FEBS Letters 556 (1) (2004) 253259. https://doi.org/10.1016/S0014-5793(03)01428-5. 
[3] O'Halloran, T. V., Culotta, V. C. J., Metallochaperones, an intracellular shuttle service for metal ions, Biol. Chem. 275 (1) (2000) 25057-25060. https://doi.org/10.1074/jbc.R000006200

[4] Fernandez, A. I., Fernandez, A. F., Perez, M. J., Nieto, T. P., Ellis, A. E., Siderophore production by Aeromonas salmonicida subsp. salmonicida. Lack of strain specificity, Dis. Aquat. Organ. 33 (1) (1998) 8792. https://doi.org/10.3354/dao033087.

[5] Linder, M. C., Schaffer, K. J., Hazeghazam, M., Zhou, C. Y. J., Tran, T. N., Nagel, G. M. J., Serum ferritin: does it differ from tissue ferritin?, Gastroenterol. Hepatol. $11 \quad$ (1) (1996) 1033-1036. https://doi.org/10.1111/j.1440-1746.1996.tb00030.x.

[6] Stearman, R., Yuan, D. S., Yamaguchi-Iwai, Y., Klausner, R. D., Dancis, A., A permease in high-affinity iron uptake in yeast, Science 271 (1) (1996) 1552-1557. Available from: <https://www.ncbi.nlm.nih.gov/pubmed/8599111\#>.

[7] Souza, J.C., Toci, A. T., Beluomini, M. A., Eiras, S. P., Spectrophotometric determination of copper(II) in sugarcane spirit using 1-(2-pyridylazo)-2-naphthol and a homogeneous ternary mixture of the solvents water, ethanol and methyl isobutyl ketone, Rev. Virtual Quim. 8 (1) (2016) 687-701. https://doi.org/10.5935/19846835.20160052 .

[8] Souza, J. C., Pezza, H. R., Pezza, L., A simple and green analytical method for determination of copper(II) in whisky and sugarcane spirit by diffuse reflectance spectroscopy, Anal. Method. 8 (1) (2016) 1867-1875. https://doi.org/10.1039/C5AY03073K.

[9] Sargentelli, V., Mauro, A. E., Massabni, A. C., Aspectos do metabolismo do cobre no homem, Quim. Nova 19 (1) (1996) 290-293. Available from: <http://quimicanova.sbq.org.br/imagebank/pdf/Vol19No 3_290_v19_n3_11.pdf>.

[10] Mosha, D., Wangabo, J., Mhinzi, G., African traditional brews: how safe are they?, Food Chem. 57 (1) (1996) 205-209. https://doi.org/10.1016/03088146(95)00192-1.

[11] Miranda, K., Dionísio, A. G. G., Pereira-Filho, E. R., Copper determination in sugar cane spirits by fast sequential flame atomic absorption spectrometry using internal standardization, Microchem. J. 96 (1) (2010) 99101. https://doi.org/10.1016/j.microc.2010.02.011.

[12] Kawanishi, S., Hiraku, Y., Murata, M., Oikawa, S., The role of metals in site-specific DNA damage with reference to carcinogenesis, Free Radical Bio. Med. 32 (1) (2002) 822-832. https://doi.org/10.1016/S08915849(02)00779-7.

[13] Rotilio, G., Carr`, M. T., Rossi, L., Ciriolo, M. R., Copper-dependent oxidative stress and neurodegeneration, IUBMB Life 50 (1) (2000) 309-314. https://doi.org/10.1080/713803724.

[14] Rottkamp, C. A., Nunomura, A., Raina, A. K., Sayre, L. M., Perry, G., Smith, M. A., Oxidative stress, antioxidants, and Alzheimer disease, Alz. Dis. Assoc. Dis. $\quad 14 \quad$ (1) (2000) 62-66. http://journals.lww.com/alzheimerjournal/pages/articlevi ewer.aspx ?year $=2000 \&$ issue $=00001 \&$ article $=00010 \&$ typ $\mathrm{e}=$ abstract.

[15] Waggoner, D. J., Bartinikas, T. B., Gitlin, J. D., The role of cooper in neurodegenerative disease, Neurolobiol. Dis. $6 \quad$ (1) 221-230. https://doi.org/10.1006/nbdi.1999.0250.

[16] Wecker, L., Miller, S. B., Cochran, S. R., Dugger, D. L., Johnson, W. D. J., Trace element concentrations in hair from austitic children, Ment. Defic. Res. 29 (1) (1985) 15-22. https://doi.org/10.1111/j.13652788.1985.tb00303.x.

[17] Brasil, ministério da agricultura, pecuária e abastecimento. Diário Oficial da União, 2005. Seção 1, pp $3 . \quad$ Available from: $<$ http://extranet.agricultura.gov.br/sislegis-

consulta/consultarLegislacao.do?operacao=visualizar\&id $=12386>$. [Acessed 29 april 2017].

[18] Cardoso, D. R., Lima Neto, B. S., Franco, D. W., Influência do material do destilador na composição química das aguardentes de cana. Parte II, Quim. Nova 26 (1) 165-169. https://doi.org/10.1590/S010040422003000200004

[19] Nascimento, R. F., Cardoso, D. R., Lima Neto, B. S., Franco, D. W., Farias, J. B., Influência do material do alambique na composição química das aguardentes de cana-de-açúcar, Quim. Nova 21 (1) (1998) 735-739. https://doi.org/10.1590/S0100-40421998000600013.

[20] Lima Neto, B. S., Franco, D. W., Aguardente e o controle químico de sua qualidade, Engarraf. Moderno 33 (1) (1994) 5-8. Available from: <http://www.scielo.br/scielo.php?script=sci_nlinks\&ref $=0$ 00080\&pid $=$ S1413-7054200300030001700008\&lng=pt $>$.

[21] Boza, Y., Horii, J., Influência do grau alcoólico e da acidez do destilado sobre o teor de cobre na aguardente, Food Sci. Technol. 20 (1) (2000) 279-284. https://doi.org/10.1590/S0101-20612000000300001.

[22] Caldas, L. F. S., Francisco, B. B. A., Pereira Neto, A. D., Cassella, R. J., Multivariate optimization of a spectrophotometric method for copper determination in Brazilian sugar-cane spirits using the Doehlert design, Microchem. J. $99 \quad$ (1) (2011) 118-124. https://doi.org/10.1016/j.microc.2011.04.008.

[23] European copper institute. Technical guide on metals and alloys used as food contact, 2011. Available from: $<$ http://www.copperalliance.eu/docs/defaultsource/resources/cu-risk-assessment_coe-food-contact- 
materials---eci-comments-20110627.pdf >. [Acessed 11 February 2017].

[24] Everson, R. J., Parker, H. E., 3-heptanone vs. 4methyl-2-pentanone as extracting solvents in atomic absorption spectrophotometry, Anal. Chem. 46 (1) (1974) 2040-2042. https://doi.org/10.1021/ac60349a030.

[25] Allan J. E., The use of organic solvents in atomic absorption spectrophotometric, Spectrochim. Acta A 17 (4) (1961) 467-473. https://doi.org/10.1016/03711951(61)80099-4.

[26] Robinson J. W., Effect of organic and aqueous solvents on flame photometric emission and atomic absorption spectroscopy, Anal. Chim. Acta 23 (1) (1960) 479-487. https://doi.org/10.1016/S0003-2670(60)801110.

[27] Eiras, S. P., Custódio, U. M., Pavanin, L. A., Determination of chromium(III) using a homogenous mixture of water-ethanol-methylisobutylketone solvents,
Talanta
59
(3)
(2003)
621-625.

https://doi.org/10.1016/S0039-9140(02)00577-5.

[28] Silva, J. F., Martins, J. W., Extraction of Fe(III), $\mathrm{Cu}$ (II), $\mathrm{Co}(\mathrm{II}), \quad \mathrm{Ni}(\mathrm{II})$ and $\mathrm{Pb}$ (II) with thenoyltrifluoroacetone using the ternary solvent system water/ethanol/methylisobutylketone, Talanta 39 (10) (1992) 1307-1312. https://doi.org/10.1016/00399140(92)80242-6.
[29] Eiras, S. P., Zamora, P. G. P., Reis, E. L., Estudo do efeito de misturas de solventes na determinação espectrofotométrica por absorção atômica, Quim. Nova 17 (1) (1994) 369-371. Available from: <http://quimicanova.sbq.org.br/imagebank/pdf/Vol17No 5_369_v17_n5_\%282\%29.pdf>.

[30] Cornel, J. A., Experiments with mixtures: designs, models, and the analysis of mixture data, John Wiley \& Sons, New York, 3rd ed., 2002.

[31] Barros Neto, B., Scarminio, I. S., Bruns, R. E., Como fazer experimentos: pesquisa e desenvolvimento na ciência e indústria, UNICAMP, Campinas, 2002.

[32] Bruns, R. E., Scarmínio, I. S., Sistema computacional Arthur para microcomputadores, UNICAMP, Campinas, 1 ed., 1982.

[33] Association of Analytical Chemists, Official methods of analysis, AOAC, Arlington, 16th ed., 1997.

[34] Ribani, M., Bottoli, C. B. G., Collins, C. H. Jardim, I. C. S. F., Melo, L. F. C., Validação em métodos cromatográficos e eletroforéticos, Quim. Nova 27 (5) (2004) 771-780. https://doi.org/10.1590/S010040422004000500017.

[35] Associação brasileira de bebidas. Destilados, 2017. Available from: <http://www.abrabe.org.br/categorias/>. [Acessed: 15 March 2017]. 